\title{
The Influence OF Changes of Body Composition PaRameters in THE ReCOVERY PERIOD IN TOP ATHLETES
}

\author{
Iva Šeflová ${ }^{1}$; Soňa Jandová ${ }^{2}$; Kristýna Mrázková \\ ${ }^{1}$ Technical University of Liberec, Faculty of Science, Humanities and Education, \\ Department of Physical Education, Na Bohdalci 715, 46015 Liberec 15, Czech Republic \\ ${ }^{2}$ Technical University of Liberec, Studentská 1402/2, 46117 Liberec 1, Czech Republic \\ e-mail: ${ }^{1}$ iva.seflova@tul.cz; ${ }^{2}$ sona.jandova@tul.cz
}

\begin{abstract}
Abstrakt
When determining the parameters of body composition with bioimpedance based methods, it is necessary to respect a number of conditions related to the measured subjects. A frequently cited limitation is the time difference of at least $8-12$ hours between the acute physical stress and the measurement. The aim of this study was to determine the measure of the reaction changes in the body composition parameters before and during the process of recovery in top athletes and to specify the necessary time interval between the measurement and the load test $\mathrm{VO}_{2 \max }$ on a treadmill ergometer.

When measuring body composition with bioimpedance based methods immediately after stress and after 60 minutes of recovery, the changes in body composition values were neither statistically nor substantively significant; therefore, the measurement can be accomplished without distortion of the results due to, e. g., the loss or redistribution of fluids as a reaction to changes in stress. The results of our study did not prove the necessity of a minimum 8-hour interval between the load test $\mathrm{VO}_{2 \max }$ and the measurements.
\end{abstract}

\section{Keywords}

Body composition; Bioelectrical impedance; Recovery.

\section{Introduction}

Currently, the determination of body composition by bioimpedance methods is often used not only for a relatively simple, non-invasive determination of the amount of body fat and lean body mass, but also for the possibility of identifying other relevant variables describing body composition [15], [4] and nutritional status [9].

The detected variables are the body cell mass (BCM), extracellular mass (ECM), total body water (TBW), extracellular water (ECW) and intracellular water (ICW) [17].

Numerous studies have shown that the BIA method can be used with healthy individuals and specific groups of patients with stable water and electrolyte balance when using the existing prediction equation and taking into account the age, gender and race [11].

A routine use of BIA is not recommended to patients with extreme values of body mass index (BMI) and with abnormal hydration status [20]. Similarly, a further verification of the validity of BIA is desired, e.g., in the states of acute disease [7], extreme values of body weight [5], [19], [14] and an unusual abnormal body shape [6].

To determine correctly the parameters of body composition, it is important to observe a number of conditions relating to the measured people [12]. Measurements of weight and height should be done at the same time as the measurement ob BIA. There should be 
respected standardized conditions relating to the body position, the position of electrodes still on the same side of the body with a minimum distance of $5 \mathrm{~cm}$ and normal temperature of extremities; furthermore, the tested individuals must refrain from drinking alcohol for at least 24 hours prior to the measurement and eat no food for 8 hours.. No measurement during menstruation is demanded.

Another limitation is also the measurement after acute physical stress during recovery and regeneration.

Data Input [3] recommends a time interval after exercising for at least 12 hours. This time interval is mainly related to possible changes in the volume and distribution of fluids when lower hydration indicates lower reactance and resistance and even a conversely higher fluid intake of $100 \mathrm{ml}$ each over the normal state induces higher levels of resistance and reactance [13]. Kyle et al. [12] stated in recommendations for clinical application of bioelectrical impedance analysis that the BIA measurement in the time interval $<8$ hours may also be responsible for the inadequacy of BIA parameters.

Otağ et al. [16] investigated a number of changes before and after loading by Astrand's test on a bicycle ergometer with women in parameters the total body water, $\%$ body fat and lean body mass in relation to the phase of the menstrual cycle-related hormonal changes and hydration status.

The objective of our study is to determine the amount of changes in parameters of body composition measured by bioimpedance methods before and during loading and the recovery processes and to specify the necessary time interval between the BIA measurement and the test of maximum oxygen consumption $\left(\mathrm{VO}_{2 \max }\right)$.

\section{$1 \quad$ Methodology}

Our project was attended by 45 people - athletes dealing with regular sports activities 6-8 times a week (Basic characteristics in Table 1).

Tab. 1: Basic characteristics of the tested people (arithmetic mean $\pm S D$ )

\begin{tabular}{|l|l|l|l|l|l|}
\hline Quantity & Age [years] & Height [cm] & Weight [kg] & Fat mass [\%] & $\mathrm{VO}_{2 \max }[\mathrm{ml} / \mathrm{kg} / \mathrm{min}]$ \\
\hline 45 & $16.21 \pm 1.09$ & $176.58 \pm 6.14$ & $66.9 \pm 7.90$ & $9.80 \pm 1.76$ & $66.65 \pm 5.56$ \\
\hline
\end{tabular}

Source: Own

The parameters of body composition have been determined by the methods of bioelectrical impedance. We have used BIA devices $2000-\mathrm{M}$, which measures the total impedance by using a frequency of $1,5,50$ and $100 \mathrm{kHz}$. Measurement is performed by the tetrapolar electrode configuration of 4 leads on the extremities of the same side of the body in the supination position (middle of metacarpal bones, wrist, middle of metatarsal bones, ankle).

On the basis of the input variables age, weight and body height, the BIA 2000 device - M determines the phase angle, total body water and its intracellular ICW and extracellular ECW constituents. It also allows to determine the values of BCM (characterizes the number of cells capable of using oxygen, the cells rich in calcium and cells that are able to oxidize sugars), extracellular mass ECM (portion of lean body mass outside the cells) and their ratio [3].

The percentage of body fat and lean body mass for the age group was calculated subsequently according to the prediction equations by Bunc et al. [1]. Body composition parameters were determined immediately prior to the exercise test, immediately after completing it within 5 minutes and then 60 minutes after finishing the test. 
The tested subjects underwent $\mathrm{VO}_{2 \max }$ test on the treadmill ergometer. It consisted of a total of $2 \times 4$ minutes of submaximal load at speeds of 8 and $10 \mathrm{~km} / \mathrm{h}$ with the zero slope of the treadmill followed by the graded test to vita maxima at the $5 \%$ slope starting at $10 \mathrm{~km} / \mathrm{h}$ and an acceleration of $1 \mathrm{~km} / \mathrm{h}$ every minute.

To evaluate changes in the body composition before loading and post-exercise phase, we used a paired $t$-test for the median value (by Student). In this project, we compare the so-called value pairs and talk about dependent samples (repeated measurements at a single file).

Normal distributed samples are the basic condition for using a $t$-test. To verify the orientation distribution of all observed data measured in a group of 45 people, we used the programme NCSS and the function for verifying normality of distribution as a prerequisite for using the $t$ test.

For all variables, we set the boundaries of reliability $p$ according to Table 2 .

Tab. 2: The significance of boundaries to determine statistical significance

\begin{tabular}{|l|l|l|}
\hline$p>0.05$ & insignificant (statistically insignificant) & symbol - \\
\hline$p \leq 0.05$ & significant (statistically significant) & symbol * \\
\hline$p \leq 0.01$ & highly significant (statistically highly significant) & symbol ** \\
\hline
\end{tabular}

To assess the significance of the subject, we considered the following values: parameters of body composition such as body fat $\%, 0.50 \%$, the ATH $0.5 \mathrm{~kg}$, and the ratio of ECM / BCM 0.03 .

For resistance values at $50 \mathrm{kHz}$, we considered as significant changes those greater than $10 \Omega$, TBW 0.85 litres, ICW 0.52 litres, ECW 0.42 litres.

The technical error of the BIA 2000 device indicated by the manufacturer [3] ranges up to $2 \%$ and the error of weight measurement and condition of the body in terms of hydration and nutrition is also reflected in each of the measured parameters of body composition.

To evaluate the significance of the subject, we used the relative Hays's coefficient $\omega^{2}$ which Blahuš [21] recommends in a double assessment of substantive significance, both in absolute real size in units of measurement and also in explaining the percentage of variance. For our project, we set the limit of significance $\omega^{2}>0.40$. The relative Hays's coefficient is calculated according to the formula (1)

$$
\omega^{2}=\frac{t^{2}}{t^{2}+(n-1)},
$$

where $t$ is the $t$-test value and $n$ is the number of elements.

\section{$2 \quad$ Results}

Table 3 displays the results of measurements of body composition before the load, after the load within 5 minutes and 60 minutes after the load with a statistical significance of changes. 
Tab. 3: Results of measurements of body composition before the load (measurement 1), after the load within 5 minutes (measurement 2) and 60 minutes after the load (measurement 3 ) with a statistical significance of changes

\begin{tabular}{|c|c|c|c|c|c|c|}
\hline & \multicolumn{2}{|c|}{ Measurement 1} & \multicolumn{2}{|c|}{ Measurement 2} & \multicolumn{2}{|c|}{ Measurement 3} \\
\hline & Mean & SD & Mean & SD & Mean & $\mathrm{SD}$ \\
\hline Resistance $50 \mathrm{kHz}$ & 492.91 & 36.25 & $482.49 * *$ & 37.21 & $489.91-$ & 38.70 \\
\hline Phase angle & 7.10 & 0.64 & $7.20-$ & 1.21 & $7.27-$ & 1.21 \\
\hline TBW (total body water) & 42.63 & 4.45 & $43.21 * *$ & 4.71 & $42.77-$ & 4.61 \\
\hline ECW (extracellular water) & 16.68 & 2.52 & $17.10^{* *}$ & 2.70 & $16.79-$ & 2.62 \\
\hline ICW (intracellular water) & 25.95 & 1.99 & $26.12 *$ & 2.12 & $25.98-$ & 2.05 \\
\hline ECM (extracellular mass) & 25.17 & 2.97 & $25.59 * *$ & 3.07 & $25.18-$ & 2.99 \\
\hline BCM (body cell mass) & 33.06 & 3.87 & $33.45^{* *}$ & 4.07 & $33.26-$ & 4.00 \\
\hline $\mathrm{ECM} / \mathrm{BCM}$ & 0.77 & 0.08 & $0.77-$ & 0.08 & $0.76-$ & 0.08 \\
\hline$\%$ TT (percentage of fat mass) & 9.08 & 1.78 & $8.99 * *$ & 1.77 & $9.05-$ & 1.77 \\
\hline ATH (lean body mass) & 60.71 & 6.33 & $60.77 * *$ & 6.37 & $60.73-$ & 6.36 \\
\hline
\end{tabular}

\section{$2.1 \quad$ Resistance $50 \mathrm{kHz}$}

The highest values were measured before the exercise test, while the lowest immediately after loading. Statistically significant changes only occurred between the $1^{\text {st }}$ and the $2^{\text {nd }}$ measuring.

In terms of substantive significance, variations of differences were observed in resistance of $50 \mathrm{kHz}$ on the edge of the substantive significance of $10 \Omega$.

The values of the relative Hays's coefficient were insignificant in all measurement periods. The difference between the first measurement and after a 60-minute recovery period, a third measurement was not statistically significant nor factually.

\subsection{Phase Angle}

For the phase angle no statistically significant or factual changes occurred during all three measurements.

\subsection{TBW}

The values of total body water demonstrated statistically very significant changes only between the 1 st and the 2 nd measurements, which increased the values observed during the second measurement.

In terms of substantive significance, the difference between the $1^{\text {st }}$ and the $2^{\text {nd }}$ measuring 0.57 liters did not exceed the value set by us as 0.85 liters and the values of the relative Hays's coefficient are not significant. 


\section{$2.4 \quad$ ECW and ICW}

ECW and ICW values showed statistically very significant changes only between the $1^{\text {st }}$ and the $2^{\text {nd }}$ measurements, which increased the values observed during the second measurement. Factually significant difference did not exceed in either of the cases the specified level of significance, as well as the values of the relative Hays's coefficient point in all phases of measurements on minor changes.

\subsection{ECM and BCM}

These values showed statistically very significant changes between the first and the second measurements, which increased the values monitored during the second measurement in the phase of recovery.

These changes were not substantively significant even at the level of appreciation when we had set substantive significance of individual variables or when we were using the relative Hays's coefficient.

In the values of ECM / BCM ratio no statistically or substantively significant changes occurred during all measurements.

\subsection{Fat Mass}

The highest values of percentage of body fat were measured during the $1^{\text {st }}$ measurement, while the lowest ones during the $2^{\text {nd }}$ measurement. The difference in arithmetic mean was $0.09 \%$, which is lower than our stated value of factual significance. The relative Hays's coefficient also refers to minor changes.

\subsection{Lean Body Mass}

The highest value ATH was measured during the first measurement, the lowest during the second measurement. The difference in arithmetic mean was $0.06 \mathrm{~kg}$. In terms of substantive significance differences moved beneath the agreed level of substantive significance and value of the relative Hays's coefficient are in all measurement periods insignificant.

Tab. 4: Results of $V O_{2 \max }$ test

\begin{tabular}{|l|c|c|c|c|c|c|c|c|c|c|}
\hline Quantity & Power & $\mathrm{MHR}$ & $\mathrm{VO}_{2 \max }$ & $\mathrm{VO}_{2 \max }$ & Ventilation $\max$ & $\mathrm{La}$ in 5 & $\mathrm{VO}_{2 \mathrm{ANP}}$ & $\mathrm{ANP}$ & $\mathrm{HR}_{\text {anp }}$ & $\mathrm{HR}_{\text {anp }}$ \\
\hline & $\mathrm{W}$ & $\mathrm{bpm}$ & $\mathrm{ml} / \mathrm{min}$ & $\mathrm{ml} / \mathrm{min} / \mathrm{kg}$ & litres & $\mathrm{mmol} / \mathrm{l}$ & $\mathrm{ml} / \mathrm{min}$ & $\%$ & $\mathrm{bpm}$ & $\%$ \\
\hline Mean & 203.33 & 199.67 & 4423.67 & 66.66 & 120.67 & 12.75 & 3307.00 & 74.67 & 178.33 & 89.33 \\
\hline $\mathrm{SD}$ & 22 & 8 & 428 & 5.17 & 16 & 3.51 & 302 & 4 & 6 & 1 \\
\hline
\end{tabular}

MHR - maximal heart rate,

Ventilation $_{\max }-$ maximal measured ventilation,

La in $5^{\prime}$ - lactate concentration in the $5^{\text {th }}$ minute after the load,

$\mathrm{VO}_{2 \mathrm{ANP}}$ - anaerobic threshold value and maximal $\%$ of $\mathrm{VO}_{2 \max }$,

$\mathrm{HR}_{\text {anp }}$ - anaerobic threshold value expressed by heart rate and maximal percentage of heart rate.

Source: Own

From Table 4 it is clear that the results of body composition were measured with the tested people after loading mixed aerobic - anaerobic character.

The values of performance, maximal oxygen consumption and ventilation are above the population norm [17] and the values at the level of the anaerobic threshold indicate on aboveaverage results [8]. 
The variables of body composition we observed remained unchanged when comparing the values before and after loading.

When comparing the data, both the first measurement before loading and the second immediately after the exercise test were in terms of factual and statistical significance in a change of resistance at $50 \mathrm{kHz}$, but this was not accompanied by any changes in the relative Hays's coefficient.

The resistance value at $50 \mathrm{kHz}$ enters besides age, height, weight and gender in prediction equation to calculate the percentage body fat and lean body mass.

Higher resistance values before the exercise test, however, are not reflected in the changes of percentage of body fat and lean body mass.

For other variables, such as body composition parameters describing quantitatively the amount and distribution of body fluid and cell mass, body fat and lean body mass, no significant changes occurred.

Likewise, no significant changes for qualitative variables such as ECM / BCM, which according to the expert study of Deurenberg et al. [4] expresses the degree of fitness of the individual, and as expressed by Bunc [2], it is an indicator of quality muscle mass in terms of correlation values with a regular kinetic program.

The overall state of bodily fluids and their redistribution during the load test $\mathrm{VO}_{2 \max }$ in our test did not have any impact on changes in body composition parameters. There was no decrease in TBW and consequent reduction in resistance values and percentage of body fat, as described in the study of Khaled et al. [10].

Likewise, there were no changes in the values of the body composition even after 60 minutes of recovery. Results of percentage of body fat and lean body mass were almost unchanged during all three measurements. In comparison of individuals there were differences of up to $0.1 \%$. This value is very low and substantively insignificant. Likewise, in lean body mass investigation, the results remained almost the same in the first, the second and the third measuring and they differed maximum by about $0.1 \mathrm{~kg}$. In comparison of individuals, there was a minor change.

\section{Conclusions}

The results of our study have shown no required minimum of an 8-hour-interval after the exercise test $\mathrm{VO}_{2 \max }$. In the recovery phase no changes have occurred in each variable or immediately after loading or after 60 minutes from the test. It will be necessary to verify in future studies the nature of changes in body composition parameters after loading of a different character than the $\mathrm{VO}_{2 \max }$ test, especially after a long-term endurance performance.

\section{Acknowledgements}

This study was supported by a grant SGS 2014 from the FP TUL.

\section{Literature}

[1] BUNC, V. et al.: Závěrečná zpráva grantu 316/1997/C/FTVS. [online]. 1999. [accessed 2014-12-07]. Available from http://www1.cuni.cz/cuni/ruk/gauk/zz1999/316_97-c.htm

[2] BUNC, V.: Children's overweight and obesity - cause and consequences. International Journal of Pediatric Obesity. 2008, Volume 3 (suppl. 2), p. 37. 
[3] Data Input. Das BIA-Kompendium. [online]. 2009. [accessed 2014-12-07]. Available from WWW: http://www.data-input.de/media/pdfdeutsch/Kompendium_III_Ausgabe_2009.pdf

[4] DEURENBERG, P. et al.: Differences in body impedance hen measured with different instruments. European Journal of Clinical Nutrition. 1992, Volume 43, pp. 885-886.

[5] DEURENBERG, P.: Limitations of the bioelectrical impedance method for the assessment of body fat in severe obesity. The American Journal of Clinical Nutrition. 1996, Volume 64, Issue 3, pp. 450-452.

[6] DRISKELL, J. A.; WOLINSKY, I. (editors): Nutritional Assessment of Athletes. $2^{\text {nd }}$ ed. CRC Press, Boca Raton, Florida, 2011. ISBN 13:978-1-4398-1822-0.

[7] FAISY, C. et al.: Bioelectrical impedance analysis in estimating nutritional status and outcome of patients with chronic obstructive pulmonary disease and acute respiratory failure. Intensive Care Medicine. 2000, Volume 26, Issue 5, pp. 523-525.

[8] HELlER, J.; VODIČKA, P: Praktická cvičení z fyziologie tělesné zátěže. 1. vyd. Karolinum, Praha, 2011. ISBN 978-80-246-1976-7.

[9] HENGSTERMANN, S. et al.: Nutrition Status and Pressure Ulcer: What We Need for Nutrition Screening. Journal of Parenteral and Enteral Nutrition. 2007, Volume 31, Issue 4, pp. 291-294.

[10] KHALED, M. J. et al.: Electrical impedance in assessing human body composition: the BIA method. The American Journal of Clinical Nutrition. 1988, Volume 47, Issue 5, pp. 789-792.

[11] KYLE, U. G. et al.: Bioelectrical impedance analysis. Part I: review of principles and methods. Clinical Nutrition. 2004, Volume 23, Issue 5, pp. 1226-1243.

[12] KYLE, U. G. et al.: Bioelectrical impedance analysis. Part II: utilization in clinical practice. Clinical Nutrition. 2004, Volume 23, Issue 6, pp. 1430-1453.

[13] KYLE, U. G. et al.: Total body mass, Fat Mass, Fat-Free Mass and skeletal muscle in older people. New Medicine. 2008, Volume 12, Issue 4, pp. 90-93.

[14] LEAL, A. A. et al.: Bioimpedance analysis: should it be used in morbid obesity? American Journal of Human Biology. 2011, Volume 23, Issue 3, pp. 420-422.

[15] LUKASKI, H. C. et al.: Validation of tetrapolar bioelectrical impedance method to assess human body composition. Journal of Applied Physiology. 1986. Volume 60, Issue 4, pp. 1327-1332. [online]. [accessed 2014-12-07]. Available from WWW: http://jap.physiology.org/content/jap/60/4/1327.full.pdf

[16] OTAĞ, A. et al.: Evaluation of body composition and basal metabolic rate after acute exercise in menstrual phases in sports women. Cumhuriyet Medical Journal. 2011. Volume 33, pp. 53-60. [online]. [accessed 2014-12-07]. Available from WWW: http://dergi.cumhuriyet.edu.tr/cumucmj/article/viewFile/492/1008000709

[17] SELIGER, V.; Bartůněk, Z.: International biological programme results of investigations 1968-1974: mean values of various indices of physical fitness in the investigation of Czechoslovak population aged 12-55 years. ČSTV, Praha, 1976.

[18] Van LOAN, M. D. et al.: Use of Bioimpedance Spectroscopy to Determine Extracellular Fluid, Intracellular Fluid, Total Body Water, and Fat-Free Mass. In: Ellis, K. J.; Eastman, J. D. (eds.) Human Body Composition: In Vivo Methods, Models, and Assessment. Springer US. 1993, pp. 67-70. DOI: 10.1007/978-1-4899-1268-8_13. 
[19] VANSANT, G. et al.: Assessment of Body Composition by Skinfold Anthropometry and Bioelectrical Impedance Technique: A Comparative Study. Journal of Parenteral and Enteral Nutrition. 1994, Volume 18, pp. 427-429.

[20] DAS, S. K. et al.: Body composition assessment in extreme obesity and after massive weight loss induced by gastric bypass surgery. American Journal of Physiology Endocrinology and Metabolism. 2003, Volume 284, Issue 6, pp. E1080-E1088. DOI: $\underline{10.1152 / \text { ajpendo.00185.2002. }}$.

[21] BLAHUŠ, P.: K systémovému pojetí statistických metod empirického výzkumu chování. Karolinum, Praha, 1996. ISBN 807184-100-5.

PhDr. Iva Šeflová, Ph.D.; doc. PhDr. Soňa Jandová, Ph.D.; Bc. Kristýna Mrázková 


\section{ZMĚNY PARAMETRŮ TĚLESNÉHO SLOŽENÍ PO AKUTNÍM ZATÍŽENÍ U SPORTOVCŮ}

Při stanovení parametrů tělesného složení bioimpedančními metodami je třeba respektovat řadu podmínek týkající se měřených osob. Často uváděným omezením je odstup měření od akutního fyzického zatížení minimálně $8-12$ hodin. Cílem této studie bylo stanovit velikost reakčních změn u parametrů tělesného složení před zatížením a během procesů zotavení a specifikovat tak nutný časový odstup měření od zatížení testem $\mathrm{VO}_{2 \max }$ na běžeckém ergometru.

Při měření tělesného složení bioimpedančními metodami bezprostředně po zatížení a po 60 minutách zotavení nedošlo $\mathrm{k}$ statisticky ani věcně významným změnám u hodnot tělesného složení a lze tedy tato měření absolvovat bez zkreslení výsledků vlivem např. ztráty nebo redistribuce tekutin jako reakčních změn na zatížení. Výsledky naší studie neprokázaly nutný minimální 8hodinový odstup měření od zatížení testem $\mathrm{VO}_{2 \max }$.

\section{ÄNDERUNG DER PARAMETER DER PHYSISCHEN ZUSAMMENSETZUNG NACH} AKUTER BELASTUNG DER SPORTLER

Bei der Festlegung der Parameter einer physischen Zusammensetzung durch Bioimpedanzmethoden muss man eine Reihe von Bedingungen im Hinblick auf die gemessenen Personen beachten. Eine häufig angeführte Einschränkung besteht in einem Messabstand ab der akuten physischen Belastung von mindestens acht bis zwölf Stunden. Ziel dieser Studie ist die Festlegung der Größe der Reaktionsänderungen bei den Parametern der körperlichen Zusammensetzung vor der Belastung und während des Erholungsprozesses und die Spezifizierung eines notwendigen Zeitabstands der Messung ab der Belastung durch einen $\mathrm{VO}_{2 \max }$-Test auf einem Laufergometer.

Bei der Messung der körperlichen Zusammensetzung mit Hilfe von Impedanzmethoden unmittelbar nach der Belastung und nach 60 Minuten Ausruhen kam es bei den Werten der körperlichen Zusammensetzung weder $\mathrm{zu}$ statistisch noch $\mathrm{zu}$ sachlich relevanten Veränderungen. Man kann diese Messungen also ohne Verzerrung der Ergebnisse, z. B. durch den Einfluss von Flüssigkeitsverlust oder Flüssigkeitsredistribution als reaktive Veränderungen, absolvieren. Die Ergebnisse unserer Studie wiesen keinen notwendigen mindestens achtstündigen Messabstand ab der Belastung durch den $\mathrm{VO}_{2 \max }$-Test auf.

\section{ZMIANY PARAMETRÓW SKŁADU CIAŁA PO NAGŁYM WYSIŁKU FIZYCZNYM}

Określając parametry składu ciała przy pomocy metod bioimpedancji należy uwzględnić wiele czynników dotyczących badanych osób. Często wskazywanym ograniczeniem jest przeprowadzanie pomiarów po upływie co najmniej 8-12 godzin po nagłym wysiłku fizycznym. Celem przeprowadzonych badań było określenie wielkości zmian wywoływanych wysiłkiem w przypadku parametrów składu ciała przed aktywnością fizyczną i w czasie procesów regeneracji powysiłkowej oraz wskazanie niezbędnego czasu, jaki powinien upłynąć pomiędzy badaniem (pomiarem) a wysiłkiem na ergometrze do biegania podczas testu wysiłkowego $\mathrm{VO}_{2 \max }$.

W przypadku pomiarów składu ciała dokonywanych przy pomocy metod bioimpedacyjnych, przeprowadzanych bezpośrednio po wysiłku i po upływie 60 minut regeneracji powysiłkowej, nie odnotowano statystycznie ani przedmiotowo istotnych zmian w wartościach składu ciała. A więc przykładowo utrata lub redystrybucja płynów, będące zmianą reagującą na wysiłek, nie powodują zniekształcenia wyników pomiarów. Wyniki naszych badań nie wskazały na konieczność zachowania co najmniej ośmiogodzinnego odstępu czasu pomiędzy pomiarem a testem wysiłkowym $\mathrm{VO}_{2 \max }$. 